\title{
A Review of Production and Processing of Kiwifruit
}

Guroo I*, Wani SA, Wani SM, Ahmad M, Mir SA and Masoodi FA

Department of Food Science and Technology, University of Kashmir, Srinagar, India

\begin{abstract}
Kiwifruit is native to Asia and has become popular worldwide due to its sensory and nutritional properties. It contains high levels of bioactive compounds such as vitamin $\mathrm{C}$ vitamin $\mathrm{E}$, flavonoids, carotenoids and minerals. Kiwifruits show a wide diversity in size, shape, fuzziness, flesh and peel color and flavor. The export of fresh kiwifruit has led to rapid expansion of kiwifruit industry through out the world. kiwifruit has become a commonly consumed fruit and is easily available round the year. Kiwifruit is largely consumed as fresh but it is also available in processed forms as juices, fortified drinks, candies, dehydrated and lyophilized products. Kiwifruit is also minimally processed to provide consumers with ready to eat products. Different preservation techniques have been used so far to preserve minimally processed kiwifruit. Here we are going to review some of these techniques.
\end{abstract}

Keywords: Kiwifruit; Minimal processing; Production; Composition; Health benefits

\section{Introduction}

Kiwifruit is well known for its flavour and vitamin C content. It is a climacteric fruit and is very sensitive to ethylene. Botanically, kiwifruit is a berry with various locules filled with numerous small and soft black seeds. Its flesh is divided into three regions: the outer pericarp, the inner pericarp with seeds, and the columella (core). Each part differs from the others in terms of composition and texture. The columella is lighter than the inner and outer pericarps. Kiwifruit belongs to family Actinidiaceae and genus Actinidia. The genus Actinidia has 76 species and about 125 known taxa worldwide [1], but among these only two species Actinidia deliciosa (fuzzy kiwifruit) and Actinidia chinensis (golden kiwifruit) have been produced commercially [2]. Other species of Actinidia include: A. arguta (baby kiwifruit), A. kolomikta (Arctic kiwifruit), A. purpurea (purple kiwifruit), A. polygama (silver vine), $A$. eriantha (Velvet vine) and $A$. melanandra (red kiwifruit). The species A. arguta, A. Kolomikta, A. purpurea can also grow in cooler regions due to their frost resistance [3]. Among all these species, Actinidia deliciosa, the fuzzy kiwifruit has larger fruit size and productivity, lower respiration rate and ethylene sensitivity and thus longest storage. This fruit has a fuzzy, dull-brown skin, and bright-green flesh.

The species Actinidia chinensis has a smooth, bronze skin, with a beak shape at the stem attachment. Flesh colour varies from bright green to a clear intense yellow. This species is sweeter and more aromatic in flavor. The yellow fruit fetches a higher market price and, being less hairy than the fuzzy kiwifruit, is more palatable for consumption without peeling. But, it has a short storage life which limits its commercialization. One of the most attractive varieties of this species has a red 'iris' around the center of the fruit and yellow flesh outside. Hort16A is a variety of Actinidia chinensis marketed worldwide in decreasing volumes because this variety suffered significant losses in New Zealand from late 2010 to 2013 due to the PSA bacterium. A new variety of golden kiwifruit, 'Gold3', marketed by Zespri under the trade name 'SunGold' has been found to be more disease-resistant but is not quite as sweet as the Hort16A, with a hint of tanginess.

Berries of Actinidia arguta are characterized by rapid softening, followed by significant dehydration during storage. The species Actinidia melanandra (red kiwifruit) is a dioecious climbing plant and produces clusters of large reddish green grape-like berries that are sweeter and more intensely flavoured than the fuzzy kiwifruit-Actinidia deliciosa. A. melanandra berries have a smooth texture and can be consumed as a whole. This heavily producing species is considerably winter-hardy and survive at temperatures upto $-20^{\circ} \mathrm{C}$ [4]. This species has been used for breeding of new cultivars by crossing with different $A$. arguta genotypes. Hybrid cultivar A. arguta $\times A$. melanandra 'Ken's Red' is a well known cultivar. Berries of $A$. melanandra accumulate different biologically active compounds. These berries have been characterized by exceptionally high antioxidant activity. However, this species is not well known and has not been studied sufficiently. Also, due to its short shelf-life, it cannot be produced commercially.

\section{Production}

The most widely planted kiwifruit cultivar is the fuzzy kiwifruit A. deliciosa- 'Hayward'. 'Hayward' accounts for about half of kiwifruit cultivation throughout the world. 'Hayward' kiwifruit also represents about $90 \%$ to $95 \%$ of the kiwifruit traded internationally [5]. The fuzzy kiwifruit $A$. deliciosa is commercially the most important crop and its total production accounts for about 1.8 million tons per year. However, internationally kiwifruit is a minor crop representing about $0.2 \%$ to $0.3 \%$ of total fresh fruit production [6,7]. In terms of "marketable gross production" (essentially, crop value), kiwifruit is the sixth most valuable fruit crop after citrus, apples, table grapes, peaches/nectarines, and pears. China is the largest producer of kiwifruit followed by Italy, New Zealand, Chile and Greece (Table 1). Kiwifruit is the national fruit of China. Until recently, China was not a major producer of kiwifruit, as it was traditionally collected from the wild. In China, it is grown mainly in the mountainous area upstream of the River Yangtze. In New Zealand, nearly about 2,500 farmers are associated with the kiwifruit production and they harvest about 3.7 billion kiwifruits per year. New Zealand kiwifruits are marketed in about 55 countries under the brandname Zespri. In New Zealand, kiwifruit is mainly cultivated in the Bay of Plenty (North Island). This area receives enough sunlight and rainfall, remains cool in winter and also there is no risk of frost in spring, thus provides ideal conditions for kiwifruit plantation. Although, Italy is one

*Corresponding author: Ishrat Guroo, Department of Food Science and Technology, University of Kashmir, Srinagar, India, Tel: +91- 9419135876; E-mail: ijguroo@gmail.com

Received September 20, 2017; Accepted October 11, 2017; Published October 18, 2017

Citation: Guroo I, Wani SA, Wani SM, Ahmad M, Mir SA, et al. (2017) A Review of Production and Processing of Kiwifruit. J Food Process Technol 8: 699. doi: 10.4172/2157-7110.1000699

Copyright: ( 2017 Guroo I, et al. This is an open-access article distributed unde the terms of the Creative Commons Attribution License, which permits unrestricted use, distribution, and reproduction in any medium, provided the original author and source are credited. 
of the biggest producers of kiwifruit, the industry there is still relatively small when considered in context of total Italian fruit production. In Italy, kiwifruit accounts for about $3.5 \%$ of the total area in fruit crops and about $4 \%$ of the total fruit production by weight.

Currently about 1.5-1.6 million MT of kiwifruit are produced each year. About two-third of current kiwifruit plantings are in the northern hemisphere and one-third in the southern hemisphere. Table 2 shows the production of different kiwifruit in different countries. Chile, Italy, and New Zealand together represent about $80 \%$ of the international kiwifruit exports. From the past several years, Italy and New Zealand

\begin{tabular}{|c|c|c|}
\hline Rank & Country & Production (MT) \\
\hline 1 & China & $1,765,847$ \\
\hline 2 & Italy & 447,560 \\
\hline 3 & New Zealand & 382,337 \\
\hline 4 & Chile & 255,758 \\
\hline 5 & Greece & 162,800 \\
\hline 6 & France & 55,999 \\
\hline 7 & Turkey & 41,635 \\
\hline 8 & Iran & 31,603 \\
\hline 9 & Japan & 29,225 \\
\hline 10 & United States & 27,300 \\
\hline \multicolumn{2}{|c|}{$\mathbf{2 , 8 6 5 , 1 1 8}$} \\
\hline
\end{tabular}

Table 1: Top kiwifruit-producing countries in 2013 (UN Food and Agriculture Organization)

\begin{tabular}{|c|c|}
\hline Countries & Production (t) \\
\hline Northern Hemisphere & $1,269,449$ \\
\hline China* $^{*}$ & 450,000 \\
\hline France & 65,600 \\
\hline Greece & 44,300 \\
\hline Iran $^{+}$ & 50,000 \\
\hline Italy & 466,540 \\
\hline Japan & 32,700 \\
\hline United States (California) & 2,859 \\
\hline other & 38,450 \\
\hline Southern Hemisphere & 455,823 \\
\hline Chile & 59,203 \\
\hline New Zealand & 25,820 \\
\hline other & 3,800 \\
\hline Total World & $1,725,272$ \\
\hline
\end{tabular}

Estimates based on Huang and Ferguson [1]

-Estimates based on data presented to IKO in previous years. Other estimates for Iran are much lower, c. $35000 \mathrm{t}$ [8].

Table 2: World kiwifruit (Actinidia spp.) production, all cultivars, 2006, based mainly on data presented at the 2007 IKO (International Kiwifruit organization) meeting in Chile (R. A. Martin pers. comm.).

\begin{tabular}{|c|c|c|c|c|c|c|}
\hline Cultivars & Water & Total Sugar & Total Acid & Dietry fibre & Pectin*(mg) & Vit. C" \\
\hline Abbott & 82.05 & 11.58 & 1.99 & 2.64 & 564 & 38.2 \\
\hline Bruno & 82.95 & 10.47 & 2.34 & 3.05 & 552 & 132.7 \\
\hline Fatma & 79.58 & 13.29 & 3.05 & 3.12 & 602 & 26.3 \\
\hline Gracie & 83.6 & 11.43 & 2.21 & 2.67 & 377 & 98.3 \\
\hline Elmwood & 84.8 & 8.05 & 2.16 & 2.5 & 462 & 125.4 \\
\hline $\begin{array}{c}\text { Hayward cl. } \\
\text { Priori }\end{array}$ & 83.25 & 11.92 & 2.11 & 2.25 & 410 & 93 \\
\hline $\begin{array}{c}\text { Hayward cl. } \\
\text { Tenna }\end{array}$ & 86.5 & 11.53 & 2.61 & 2.13 & 462 & 66.2 \\
\hline Hayward & 84.05 & 10.51 & 1.92 & 2.6 & 392 & 59.1 \\
\hline Monty & 84.83 & 9.72 & 1.95 & 2.74 & 397 & 70.7 \\
\hline
\end{tabular}

*As galacturonic acid equivalents. "( $\mathrm{mg} / 100 \mathrm{~g} \mathrm{FW})$

Table 3: Composition of nine kiwifruit cultivars ( $g / 100 \mathrm{~g} \mathrm{FW}$ ).

\begin{tabular}{|c|c|c|c|}
\hline Cultivars & Quinic & Malic & Citric \\
\hline Abbott & 0.45 & 0.41 & 1.06 \\
\hline Bruno & 0.51 & 0.36 & 1.42 \\
\hline Fatma & 0.71 & 0.34 & 1.95 \\
\hline Gracie & 0.30 & 0.29 & 1.56 \\
\hline Elmwood & 0.45 & 0.34 & 1.30 \\
\hline Hayward cl. Priori & 0.40 & 0.28 & 1.35 \\
\hline Hayward cl. Tenna & 0.53 & 0.36 & 1.68 \\
\hline Hayward & 0.39 & 0.24 & 1.20 \\
\hline Monty & 0.43 & 0.37 & 1.10 \\
\hline
\end{tabular}

Table 4: Organic acid content of nine kiwifruit cultivars (g/l00 g FW) (Lintas et al., 1991).

are competing for the position of world's largest exporter of kiwifruit, and currently New Zealand is slightly ahead [6,7]. These two countries export nearly twice as that of Chile, the next largest exporter of kiwifruit. During 2005-2007, New Zealand exported about 314000 t, Italy 27000 $\mathrm{t}$, and Chile $45000 \mathrm{t}$ kiwifruit per year [6].

New Zealand and Chile export more than $90 \%$ of their kiwifruit production, whereas Italy exports about three quarters of its total kiwifruit production. The difference in imports is even more striking: Chile and New Zealand both import negligible quantities of kiwifruit whereas Italy imports about $5000 \mathrm{t}$ of kiwifruit per year. Italy imports large quantities of kiwifruit during its off-season but for the rest of the year it is one of the largest exporter [6]. More than half of the kiwifruit import in italy comes from Chile, representing about $20 \%$ of Chile's total kiwifruit exports. Italy starts its kiwifruit exports early in September which peaks up in December and lasts upto April period [6]. New Zealand exports its kiwifruit from mainly between May and November. There occurs an overlap of the kiwifruit supplies in Europe, particularly at the beginning of the Italian harvest which leads to lowering of returns, especially during the European winter when most kiwifruits come from Italy. The cultivars that are harvested earlier also increase the overlap; likewise, increased exports of fruit as production expands in different countries may result in further competition and its subsequent effects on fruit returns.

\section{Composition}

Fruits are one of the major dietary sources of various antioxidant phytocompounds for humans. Fruits of Actinidia species are excellent sources of vitamin $C$ [8]. As one of the most popular fruits today, kiwifruit is characterized by a high content of vitamin $\mathrm{C}$ and other useful compounds such as vitamin E, flavonoids, and minerals [9]. It also contains significant amounts of pigments, including chlorophylls and carotenoids [10]. Tables 3 and 4 shows the composition of different kiwifruit cultivars.

Kiwifruit is well known for its antioxidant properties, which are influenced by their biologically active substances. A high correlation has been reported between the content of total polyphenols and antioxidant activity [9]. Recently, a new tocopherol analogue (tocomonoenol) has been identified and characterized in kiwifruit. The study about this compound reveals its involvement in the total antioxidant activity of kiwifruits [11]. Kiwifruit is part of a big group of fruits that are important due to their antioxidant capacity according to the ascorbic acid equivalent antioxidant capacity (AEAC). Some of the fruits that are part of this group are: chiku, with the highest antioxidant capacity, followed by strawberry, plum, star fruit, guava, seedless grape, avocado, orange, solo papaya, mango, kiwifruit, pomelo, lemon, pineapple, apple, foot long papaya, rambutan, banana, coconut pulp, tomato, rockmelon, honeydew, watermelon and coconut water [12]. 'Hardy kiwis' (Actinidia 


\begin{tabular}{|c|c|c|c|}
\hline \multicolumn{2}{|c|}{ Fuzzy kiwifruit (Actinidia delicosa) } & \multicolumn{2}{|c|}{ Golden kiwifruit (Actinidia chinensis) } \\
\hline \multicolumn{2}{|c|}{ Nutritional value per $100 \mathrm{~g}$} & \multicolumn{2}{|c|}{ Nutritional value per $100 \mathrm{~g}$} \\
\hline Energy & 255 kJ (61 kcal) & Energy & $251 \mathrm{~kJ}(60 \mathrm{kcal})$ \\
\hline Carbohydrates & $14.66 \mathrm{~g}$ & Carbohydrates & $14.23 \mathrm{~g}$ \\
\hline Sugars & $8.99 \mathrm{~g}$ & Sugars & $10.98 \mathrm{~g}$ \\
\hline Dietary fiber & $3 \mathrm{~g}$ & Dietary fiber & $2 \mathrm{~g}$ \\
\hline Fat & $0.52 \mathrm{~g}$ & Fat & $0.56 \mathrm{~g}$ \\
\hline Protein & $1.14 \mathrm{~g}$ & Protein & $1.23 \mathrm{~g}$ \\
\hline \multicolumn{4}{|c|}{ Vitamins } \\
\hline Vitamin A & $122 \mu \mathrm{g}$ & Vitamin A & $114 \mu \mathrm{g}$ \\
\hline Thiamine (B1) & $0.027 \mathrm{mg}$ & Thiamine (B1) & $0.024 \mathrm{mg}$ \\
\hline Riboflavin (B2) & $0.025 \mathrm{mg}$ & Riboflavin (B2) & $0.046 \mathrm{mg}$ \\
\hline Niacin (B3) & $0.341 \mathrm{mg}$ & Niacin (B3) & $0.28 \mathrm{mg}$ \\
\hline $\begin{array}{l}\text { Pantothenic } \\
\text { acid (B5) }\end{array}$ & $0.183 \mathrm{mg}$ & Pantothenic acid (B5) & $0.5 \mathrm{mg}$ \\
\hline Vitamin B6 & $0.063 \mathrm{mg}$ & Vitamin B6 & $0.057 \mathrm{mg}$ \\
\hline Folate (B9) & $25 \mu \mathrm{g}$ & Folate (B9) & $34 \mu g$ \\
\hline Choline & $7.8 \mathrm{mg}$ & Choline & $5 \mathrm{mg}$ \\
\hline Vitamin C & $92.7 \mathrm{mg}$ & Vitamin C & $105.4 \mathrm{mg}$ \\
\hline Vitamin E & $1.46 \mathrm{mg}$ & Vitamin $\mathrm{E}$ & $1.49 \mathrm{mg}$ \\
\hline Vitamin $\mathrm{K}$ & $40.3 \mu \mathrm{g}$ & Vitamin $\mathrm{K}$ & $5.5 \mu \mathrm{g}$ \\
\hline \multicolumn{4}{|c|}{ Minerals } \\
\hline Calcium & $34 \mathrm{mg}$ & Calcium & $20 \mathrm{mg}$ \\
\hline Iron & $0.31 \mathrm{mg}$ & Iron & $0.29 \mathrm{mg}$ \\
\hline Magnesium & $17 \mathrm{mg}$ & Magnesium & $14 \mathrm{mg}$ \\
\hline Manganese & $0.098 \mathrm{mg}$ & Manganese & $0.058 \mathrm{mg}$ \\
\hline Phosphorus & $34 \mathrm{mg}$ & Phosphorus & $29 \mathrm{mg}$ \\
\hline Potassium & $312 \mathrm{mg}$ & Potassium & $316 \mathrm{mg}$ \\
\hline Sodium & $3 \mathrm{mg}$ & Sodium & $3 \mathrm{mg}$ \\
\hline Zinc & $0.14 \mathrm{mg}$ & Zinc & $0.10 \mathrm{mg}$ \\
\hline Source: USDA Nu & nt Database & & \\
\hline
\end{tabular}

Table 5: Nutritional value of two commercially important kiwifruit cultivars

arguta) possess a rich chemical composition, which depends on the climatic and growing conditions. These fruits contain a high level of vitamin C [up to $185 \mathrm{mg} / 100 \mathrm{~g}$ fresh weight (FW)], which declines slightly during cold storage. Dietary fiber (2\% to $3 \%)$ and proteolytic enzyme actinidin, which is similar to papain, has also been determined [13]. Among all the kiwifruit cultivars, Hardy kiwis can be considered as the richest source of lutein. It was found that the concentration of phenolics in the skin of $A$. arguta was 15 times higher than in the pulp [14]. Therefore, the edible peel of hardy kiwis can significantly increase the healthful properties.

\section{Nutritional value}

The nutritional value of two commercially important kiwifruit species is given in the Table 5 .

\section{Health benefits}

In the recent years, food scientists and nutrition specialists agree that fruits and vegetables, consumed daily, contribute to reducing risks of certain diseases, including cancer and cardio and cerebrovascular diseases [15]. The various antioxidants (polyphenol, ascorbic acid, carotenoids, and tocopherols) present in fruits and vegetables contribute to these beneficial effects [16]. These antioxidants prevent diseases by scavenging radicals or by suppressing formation of free radicals by binding to metal ions, reducing hydrogen peroxide and quenching superoxide and singlet oxygen. Consumption of kiwifruit has been found to have a preventive effect against certain cancers and cardiovascular disease. Different cancers, especially cancers of the digestive system (mainly stomach cancer), lung and liver have been treated with kiwifruit prescriptions due to its cytotoxic and antioxidant activities [17]. Due to its unique composition, kiwifruit has the potential to lower the risk of cardiovascular disease [18].

\section{Pests and diseases}

White peach scale (Pseudaulacaspis pentagona) was reported as a pest on kiwifruit shortly after the first orchards were planted [19]. It is effectively controlled by the natural parasites Aphytis proclia and Encarsia berlesei if insecticides are not applied or their use has been discontinued [20].

The citrus flatid planthopper (Metcalfa pruinosa) from North America was recorded for the first time in Italy in 1979 [21]. It quickly became a pest of kiwifruit and many other fruit crops in most parts of the country. The planthopper feeds from the phloem and produces honeydew, a sweet, sticky liquid on leaf and fruit surfaces that is, in turn, colonized by sooty moulds (Capnodium sp.). Sooty mould devalues the fruit. Many other insects, often causing serious damage to other crops, are potentially serious pests of kiwifruit. Skin pitting is another serious disease of fruit that develops during cool storage. Cadophora spp. first isolated from kiwifruit stocks in Italy in 1994 [22], remains the main cause. Other fungi commonly isolated from fruits showing the same symptoms, e.g. Phomopsis, Sclerotinia, Penicillium, Rhizopus nigricans, Stemphylium and Alternaria spp. are considered more likely to be opportunistic or secondary pathogens [23].

Bacterial blossom blight is another disease of kiwifruits caused by Pseudomonas viridiflava and Ps. syringae, both of which have been isolated from diseased vines in Italy [24]. These bacteria cause blossom blight and necrotic leaf spotting, if spring is particularly wet. Growers usually spray with copper-based chemicals only if severe damage persists for several seasons. "Wood-decay" or "vine-decay" another disease associated with kiwifruits. Several pathogens have been isolated from infected wood, including Phaeoacremonium aleophilum, $P$. inflatipes, $P$. rubrigenum, Phaeomoniella chlamydospora, and Fomitiporia punctata. "Leader die-back", similar to "vine decay", is an increasingly frequent disease of A. chinensis and seems most commonly related to the presence of Cadophora luteo-olivacea [25]. Young kiwifruit vines can be lost in the nursery or after planting out from Sclerotinia, Alternaria, Fusarium, Rhizoctonia solani, Armillaria mellea, Rosellinia necatrix, and various species of Phytophthora $[23,20]$. These losses are best prevented by ensuring that the vines do not become water-logged.

\section{Harvesting}

Early ripening cultivars, such as Jintao, Summer 3373 and Summerkiwi are harvested when the soluble solids content (SSC) of the fruit reaches $6.5-7.5^{\circ}$ Brix. These cultivars are harvested several weeks before 'Hayward' so as to avoid the damage from frost, which is high towards the end of October in many kiwifruit-growing areas. Harvesting of later maturing cultivars like 'Hayward' depends on the season and particular area in which they are grown. Soluble solids content (SSC) of 'Hayward' kiwifruit reaches $6.2^{\circ}$ Brix after $160-180$ days of flowering, depending on the latitude [26]. 'Hayward' kiwifruits are generally harvested at the beginning of November. In areas, where there is no risk of frosts, harvesting can be delayed until fruit SSC reaches upto $7.5-9^{\circ}$ Brix [27]. Early harvesting between 5 and $6^{\circ} \mathrm{Brix}$ results in poor fruit quality.

\section{Storage}

Kiwifruits can be stored for 5-6 months when harvested at correct maturity and at optimal storage conditions (temperature, gas composition, relative humidity, ethylene concentration). Kiwifruits 
that are intended for sale within 3-4 months are stored under normal atmospheres [27], where as fruits that are to be kept for longer times are stored under modified atmospheres. Earlier MAP with $3 \% \mathrm{O}_{2}$ and $3 \% \mathrm{CO}_{2}$ was used, but afterwards oxygen concentrations reduced and $\mathrm{CO}_{2}$ concentrations were increased owing to the reason that higher $\mathrm{CO}_{2}$ concentrations reduce fruit respiration and hence ripening [28]. Presently kiwifruits are stored under $4.5 \%$ to $5 \% \mathrm{CO}_{2}$ and $1.8 \%$ to $2 \%$ $\mathrm{O}_{2}$ in CA stores [27]. ULO (Ultra low Oxygen) technique have also been used but it did not seem to be suitable for kiwifruit as it results in development of off-flavours and thus reduced storage life [27]. Within cool stores relative humidity is maintained above $94 \%$ to $95 \%$ that helps to reduce weight loss by $2 \%$ to $7 \%$ [29]. Kiwifruits are sensitive to ethylene and concentrations as low as $0.1-1 \mathrm{ppm}$ can induce softening [30]. In cool stores, ethylene concentrations are kept below $0.05 \mathrm{ppm}$ in order to prevent softening.

\section{Processing}

Kiwifruits are mostly eaten as fresh, although some kiwifruits are also processed into juices, fortified drinks, purees, candies, frozen, dehydrated and lyophilized products, kiwifruit leathers, distilled spirits kiwifruit preserved in syrup [31]. Actinidia delicosa - The Green kiwifruit is not usually processed due to the fact that the chlorophyll responsible for the attractive green colour gets destroyed during processing [32]. Also, the characteristic flavour of green kiwifruit gets lost. Actinidia chinensis - The Golden kiwifruit has become an alternative to food processors. In terms of processing 'Jintao' variety has shown good results, the yellow colour of the fruit survives well in processed products like juices and jams. However, high prices currently fetched by yellow-fleshed kiwifruit reduces the processing options. For the fruits that do not meet quality standards of the fresh fruit market, processing can be an alternative for adding value to the product. Small quantities of fruit that do not meet grade standards are used for cosmetics or nutraceuticals.

\section{Fresh-cut kiwifruit}

The International Fresh-cut Produce Association (IFPA) defines fresh-cut products as "any fruit or vegetable or combination thereof that has been physically altered from its original form, but remains in a fresh state". Fresh-cuts generally consist in washing, cutting, treatment with sanitizing agents, packaging and storage under refrigerated conditions The production of fresh-cut fruit and vegetables is an emerging category, because consumers look for healthy food with quality, freshness, and convenience. Moreover, today's busy consumers have no time to prepare their meals, so fresh and ready-to-eat minimally processed products become an interesting alternative [33]. A major challenge faced by the fresh-cut industry is to maintain the quality of fresh-cut produce so as to ensure consumer satisfaction and efficient marketing. Marketing of fresh-cut fruits requires a combination of appropriate strategies that would extend shelf-life while maintaining the sensory and organoleptic properties.

Minimal processing (peeling, slicing) of fresh-cut fruits causes physical damage or wounding resulting in increased respiration rates and ethylene production that reduces the shelf-life [34]. This disintegration of tissues induces some biochemical reactions that cause a change in colour (browning and chlorophyll degradation), texture loss, loss of flavour, change in nutritional quality, dehydration and vitamin oxidation. These disintegrations also lead to intermixing of enzymes, substrates and release of acid and hydrolyzing enzymes [35]. Spoilage of fresh-cuts can also increase due to transfer of microflora from peel to fruit flesh during peeling resulting in rapid growth of microorganisms, which may lead to a foodborne hazard [36]. All these factors result in softening of flesh in fresh-cut fruits. For these reasons, the shelf life of fresh-cut fruits tend to be short, and extending it even by few days could provide a considerable advantage.

\section{Preservation techniques}

Several preservation technologies including cold storage, chemical dipping, modified atmosphere and edible coatings have been used to prolong the shelf-life and retain the nutritional value of fresh-cut kiwifruits.

\section{Low temperature and chemical treatment}

As we know that minimally processed fruit and vegetables are not heat treated, regardless of the use of additives or packaging, one of the alternatives is that they must be handled and stored at refrigeration temperatures $\left(<5^{\circ} \mathrm{C}\right)$ in order to achieve a sufficient shelf-life and ensure microbiological safety [37]. Refrigeration $\left(2^{\circ} \mathrm{C}\right.$ and $\left.>90 \% \mathrm{RH}\right)$ associated with calcium chloride or calcium lactate treatment have been reported to prolong the shelf life of minimally processed kiwifruit slices up to 9-12 days [38].

\section{Modified atmosphere packaging}

Modified atmosphere packaging (MAP) is currently used for most packaged salads and fresh-cut produce. MAP in combination with alginate-based coatings delayed dehydration, microbial spoilage and respiratory activity in fresh-cut kiwifruit [39]. MAP alone is not sufficient to extend the shelf life of fresh-cut fruits. It should be used in combination with other preservation techniques in order to achieve a sufficient shelf life. Moreover, there are some disadvantages associated with MAP like high cost and loss of quality due to environmental change while transferring the fruits from modified storage environment to room temperature [40].

\section{Edible coatings}

Edible coating is the more recent and cost effective alternative to modified atmosphere packaging. Edible coatings act as an effective semipermeable barrier to respiratory gases and water vapours between the fruit and the surrounding atmosphere. These also act as barriers to microbial agents while reducing the deleterious effects of minimal processing to fresh-cut fruit [41]. Edible coatings based on polysaccharides have been used to effectively prolong the shelf life and maintain the quality of fresh-cut fruits. Alginate, a natural polysaccharide extracted from brown sea algae (Phaeophyceae) comprising of two uronic acids: $\beta$-D-mannuronic acid and $\alpha$-L-guluronic acid, have been widely used as coating in whole and fresh-cut fruits. It has been reported that alginate effectively delayed fruit dehydration and slowed down the respiratory activity in peeled kiwifruit slices [39-41]. Chitosan coating applied to red kiwifruit (Actinidia melanandra) has been found to maintain higher amounts of phenolics and ascorbic acid. Further, it also slowed down the decomposition rates [4].

In the field of edible coatings, a recent development has been the use of aloe vera gel. The mucilage or gel of the aloe vera leaf consists of approximately $99.5 \%$ water and $0.5 \%$ of solid material that includes compounds like polysaccharides, vitamins, minerals, enzymes, phenolic compounds and organic acids [42]. In a study with fresh-cut kiwifruit, Aloe vera gel effectively reduced pectin depolymerization and microbial proliferation. Furthermore, the sensorial quality also enhanced [43]. Aloe vera coating has been found to maintained the fruit firmness, prevented ascorbic acid losses and yellowing due to ripening in freshcut kiwifruit. Besides, it also reduced microbial proliferation [44]. 
Citation: Guroo I, Wani SA, Wani SM, Ahmad M, Mir SA, et al. (2017) A Review of Production and Processing of Kiwifruit. J Food Process Technol 8: 699. doi: 10.4172/2157-7110.1000699

Recently mucilage from Opuntia ficus-indica has been used as coating in fresh-cut fruits. The mucilage obtained from cladodes of cactus pear (Opuntia ficus-indica) has a highly branched complex polymeric structure of carbohydrate nature The rheological properties of O. ficus-indica mucilage make it interesting for the production of edible coatings with a high nutraceutical value. Kiwifruit slices coated with opuntia ficus-indica have been reported to maintain firmness, ascorbic acid and pectin content [45].

\section{Conclusion}

Along with the increased interest in ready-to-eat fruit with a high nutritional value, edible coatings may be a natural alternative for the production of high-quality fresh-cut kiwifruit.

\section{References}

1. Huang HW, Ferguson AR (2007) Actinidia in China: Natural diversity, phylogeographical evolution, interspecific gene flow and kiwifruit cultivar improvement. Acta Hortic 753: 31-40.

2. Zhang L, LiZZ, Wang YC, Jiang ZW, Wang SM, etal. (2010) Vitamin C, flower color and ploidy variation of hybrids from a ploidy unbalanced Actinidia interspecif cross and SSR characterization. Euphytica 175: 133-143

3. Chesoniene L, Daubaras R, Viskelis P (2004) Biochemical composition of berries of some kolomicta kiwi (Actinidia kolomicta) cultivars and detection of harvest maturity. Acta Hortic 663: 305-308.

4. Kaya M, Cesoniene L, Daubaris R, Leskauskaite D, Zabulione D (2016) Chitosan coating of red kiwifruit (Actinidia melanandra) for extending of the shelf life. Int J Biol Macromol 85: 355-360.

5. Ferguson AR, Seal AG (2008) Kiwifruit. In: Temperate Fruit Crop Breeding, Hancock, Jim F (ed) Germplasm to Genomics, East Lansing, MI, USA.

6. Belrose Inc (2007) World kiwifruit review-I. Belrose Inc, Pullman, WA.

7. Belrose Inc (2008) World kiwifruit review-II. Belrose Inc, Pullman, WA

8. Nishiyama I, Yamashita Y, Yamanaka M, Shimohashi A, Fukuda T, et al. (2004) Varietal difference in vitamin $\mathrm{C}$ content in the fruit of kiwifruit and other Actnidia species. J Agric Food Chem 52: 5472-5475.

9. Du G, Li M, Ma F, Liang D (2009) Antioxidant capacity and the relationship with polyphenols and vitamin C in Actinidia fruits. Food Chem 113: 557-562.

10. Tavarini S, Degl'Innocenti E, Remorini D, Massai R, Guidi L (2008) Antioxidant capacity, ascorbic acid, total phenols and carotenoids changes during harvest and after storage of Hayward kiwifruit. Food Chem 107: 282-288.

11. Fiorentino A, Mastellone C, D'Abrosca B, Pacifico S, Scognamiglio M, et al (2009) Tocomonoenol: A new vitamin E from kiwi (Actinidia chinensis) fruits. Food Chem 115: 187-192.

12. Dembitsky VM, Poovarodom S, Leontowicz H, Leontowicz M, Vearasilp S, et al (2011) The multiple nutrition properties of some exotic fruits: biological activity and active metabolites. Food Res Int 44: 1671-1701.

13. Yamanaka M, Oota T, Fukuda T, Nishiyama I (2004) Varietal differences in actinidin concentration and protease activity in fruit juice of Actinidia species. J Japanese Soc Food Sci Technol 51: 491-494.

14. Kim JG, Beppu K, Kataoka I (2009) Varietal differences in phenolic conten and astringency in skin and flesh of hardy kiwifruit resources in Japan. Sci Hort 120: 551-554.

15. Liu S, Manson JE, Lee IM, Cole SR, Hennekens CH, et al. (2000) Fruit and vegetable intake and risk of cardiovascular disease: The women's health study. American J Cl Nutr 72: 922-928.

16. Peschel W, Sanchez-Rabaneda F, Diekmann W, Plescher A, Gartzia I, et al. (2006) An industrial approach in the search of natural antioxidants from vegetable and fruit wastes. Food Chem 97: 137-150.

17. Collins AR, Harrington V, Drew J, Melvin R (2003). Nutritional modulation of DNA repair in a human intervention study. Carcino 24: 511-515.

18. Gammon CS, Kruger R, Minihane AM, Conlon CA, Von Hurst PR, et al (2012) Kiwi fruit consumption favourably affects plasma lipids in a randomized controlled trial in hypercholesterolemic men. $\mathrm{Br} \mathrm{J}$ Nutr 14: 1-11.
19. Ugolini A, Brussino G (1977) An avidness of Actinidia: Pseudaulacaspis pentagona (Targ.). Informatore Fitopatologico 27: 11-12.

20. Ponti I, Pollini A (1996) Actinidia's phytosanitary defense in integrated production disciplines. Societa Orticola Italiana, Faenza, Italy pp: 145-149.

21. Zangheri S, Donadini $P$ (1980) Coming in the veneto of a neartic emotion: Metcalfa pruinosa Say (Homoptera, Flatidae). Redia 63: 301-305.

22. Marchi A, Folchi A, Pratella GC (1994) Phialophora spp. agent of epidermal musculature on fruits of actinidia in refrigerated storage. Rivista di Frutticoltura e di Ortofloricoltura 56: 73-74.

23. Ugolini A (1992) Updates on the advent of Actinidia. L'Informatore Agrario 48 : 67-70.

24. Balestra GM, Varvaro L (1997) Pseudomonas syringae pv. syringae causal agent of disease on floral buds of Actinidia deliciosa (A. Chev.) Liang et Ferguson in Italy. J. Phytopathol 145: 375-378.

25. Riccioni L, Manning M, Valvassori M, Haegi A, Casonato S, et al. (2007) A new disease: Leader die-back in Actinidia chinensis 'Hortl6A' in Italy. Acta Hortic 753: 669-675.

26. Gorini F (1992) Quality, preservation and transformation of the fruits of Actinidia. L'Informatore Agrario 48: 71-74.

27. Brigati S, Donati I (2003) Actinidia: Search results for their applications in the field of conservation and commercial distribution. Societa Orticola Italiana Verona, Italy. pp: 277-290.

28. Sozzi A, Testoni A, Youssef J, Deluisa A, Nardin C (1980) Preservation of Actinidia in controlled atmosphere. Annali Experimental Institute for the Technological Valorization of Agricultural Products, Italy 11: 271-288.

29. Nardin C, Galliano A (1988) Technologies for refrigerant preservation of the product. Proceedings on Actinidia. Saluzzo, 27-28 May. Pp. 135-150.

30. Monzini A, Gorini F (1986) Aspects and problems of preservation of Actinidia: Cultivation of Actinidia. Italian Horticultural Society, Verona, Italy. pp: 141-170.

31. Cassano A, Donato L, Drioli E (2007) Ultrafiltration of kiwifruit juice: Operating parameters, juice quality and membrane fouling. J Food Eng 79: 613-621.

32. Torreggiani D, Forni E, Pelliccioni L (1994) Modification of glass transition temperature by osmotic dehydration and kiwi color frozen stability: Research and innovation in the food industry. Pinerolo pp: 621-630.

33. Oms-Oliu G, Rojas-Grau MA, Gonzalez A, Varela P, Soliva-Fortuny G, et al (2010) Recent approaches using chemical treatments to preserve quality of fresh-cut fruit: A review. Postharvest Bio Technol 57: 139-148.

34. Abe K, Watada AE (1991) Ethylene absorbent to maintain quality of lightly processed fruits and vegetables. J Food Sci 56: 1589-1592.

35. Watada AE, Abe K, Yamuchi N (1990) Physiological activities of partially processed fruits and vegetables. Food Technol 44: 116-122.

36. Rico D, Martin-Diana AB, Barat JM, Barry-Ryan C (2007) Extending and measuring the quality of fresh-cut fruit and vegetables: A review. Trend Food Sci Technol 18: 373-386

37. Ahvenainen R (1996) New approaches in improving the shelf-life of minimally processed fruit and vegetables. Trends in Food Sci Technol 7: 179-187.

38. Agar IT, Massantini R, Hess-Pierce B, Kader AA (1999) Postharvest $\mathrm{CO}_{2}$ and ethylene production and quality maintenance of fresh-cut kiwifruit slices. J Food Sci 64: 433-440.

39. Mastromatteo M, Mastromatteo M, Conte A, Del Nobile MA (2011) Combined effect of active coating and MAP to prolong the shelf life of minimally processed kiwifruit (Actinidia deliciosa cv. Hayward). Food Res Int 44: 1224-1230.

40. Torres JA (1994) Edible film and coating from protein: Protein functionality in food systems. Marcel Dekker, New York.

41. Correa-Betanzo J, Jacob JK, Perez-Perez C, Paliyath G (2011) Effect of a sodium caseinate edible coating on berry cactus fruit (Myrtillocactus geometrizans) phytochemicals. Food Res Int 44: 1897-1904.

42. Boudreau MD, Beland FA(2006)An evaluation of the biological and toxicologica properties of Aloe Barbadensis (Miller), Aloe vera. J Env Sci Health-part C 24 103-154.

43. Benitez S, Achaerandio I, Pujola M, Sepulcre F (2013) Aloe vera based edible coatings improve the quality of minimally processed 'Hayward' kiwifruit. Postharvest Biol Technol 81: 29-36. 
Citation: Guroo I, Wani SA, Wani SM, Ahmad M, Mir SA, et al. (2017) A Review of Production and Processing of Kiwifruit. J Food Process Technol 8: 699. doi: 10.4172/2157-7110.1000699

Page 6 of 6

44. Benitez S, Achaerandio I, Pujola M, Sepulcre F (2015) Aloe vera as an alternative to traditional edible coatings used in fresh-cut fruits: A case of study with kiwifruit slices. LWT - Food Sci Technol 61: 184-193.
45. Allegra A, Inglese P, Sortino G, Settanni L, Todaro A, et al. (2016) The influence of opuntia ficus-indica mucilage edible coating on the quality of Hayward kiwifruit slices. Postharvest Biol Technol 120: 45-51. 